\title{
Breeding biology and distyly in Palicourea rigida H. B. \& K. (Rubiaceae) in the Cerrados of Central Brazil
}

\author{
Adriana de Oliveira Machado', Ana Palmira Silva², Helder Consolaro ${ }^{3}$, \\ Mariluza A. Granja e Barros² and Paulo Eugênio Oliveira ${ }^{1,4}$
}

Recebido em 27/07/2009. Aceito em 18/05/2010

\begin{abstract}
RESUMO - (Biologia reprodutiva e distilia em Palicourea rigida H. B. \& K. (Rubiaceae) em Cerrados do Brasil Central). A distilia é um polimorfismo floral mais freqüente entre as espécies de Rubiaceae do que em qualquer outro grupo das Angiospermas. Palicourea rigida é uma espécie de Rubiaceae, amplamente distribuída nos cerrados brasileiros e em outras áreas de savanas neotropicais. O presente trabalho buscou estudar a biologia floral e reprodutiva de populações de $P$. rigida comparando as características associadas à heterostilia e a ocorrência de assimetrias entre os morfos florais. $\mathrm{O}$ trabalho foi realizado na Fazenda Água Limpa, Brasília, entre 1993 e 1995; no Parque Estadual da Serra de Caldas Novas-GO e na RPPN do Clube Caça e Pesca Itororó de Uberlândia-MG em 2005 e 2006. As populações foram caracterizadas quanto à densidade, altura e razão entre morfos dos indivíduos floridos. Foram investigadas diferenças na morfometria, produção de néctar, sucesso reprodutivo e reações de incompatibilidade. A floração foi longa, praticamente durante toda a estação chuvosa. As flores eram claramente distílicas e com hercogamia recíproca, apresentaram néctar como recompensa e duraram apenas um dia. Apesar de diferirem em densidade e altura dos indivíduos, as populações foram predominantemente isopléticas. A produção de néctar variou em volume e concentração, mas não foi associada a cada um dos morfos. A espécie mostrou-se marcadamente autoincompatível, mas o sucesso reprodutivo foi sempre alto e independente do morfo floral. Houve diferença nos locais de formação das barreiras de incompatibilidade semelhante ao observado para outras Rubiaceae. Os principais visitantes florais e polinizadores foram os beija-flores Colibri serrirostris e Eupetomena macroura. A alta produção de frutos indica que os polinizadores efetivamente transportaram quantidades suficientes de grãos de pólen compatíveis entre os morfos, apesar de comumente apresentarem comportamento territorial.
\end{abstract}

Palavras-chave: autoincompatibilidade heteromórfica, beija-flores, heterostilia, savanas neotropicais

ABSTRACT - (Reproductive biology and distyly in Palicourea rigida H. B. \& K. (Rubiaceae) in the Cerrados of Central Brazil). Distyly is a floral polymorphism more common among the Rubiaceae than in any other angiosperm group. Palicourea rigida is a typically distylous species of the Rubiaceae widely distributed in the Brazilian Cerrados. This work aimed to study the floral biology and breeding system of P. rigida in order to verify if there was asymmetry between floral morphs. The work was carried out at Fazenda Água Limpa, Brasília-DF, from 1993 to 1995; and at Serra Caldas Novas State Park-Goias and in Clube Caça e Pesca Itororó de Uberlândia-Minas Gerais in 2005 and 2006. Density, height and pin/thrum ratio were assessed for flowering individuals in all areas. Plants were investigated for differences in floral morphology, nectar production, reproductive success and site of self incompatibility reactions. Blooming period was long and concentrated during the rains. Flowers were clearly distylous and with reciprocal herkogamy. They produced nectar and lasted for a single day. In spite of differences in density and height, populations were mostly isoplethic. Nectar production varied in volume and concentration but the differences could not be associated with floral morphs. The species is self-incompatible but reproductive success was always high and independent of floral morphs. There were differences in the site of incompatibility barriers between floral morphs, which were similar to those observed for other Rubiaceae. The main floral visitors and pollinators were the hummingbirds Colibri serrirostris and Eupetomena macroura. High fruit-set indicates that the pollinators transported enough compatible pollen grains between floral morphs, despite their territorial behavior.

Key words: heterostyly, tropical savanna, heteromorphic self-incompatibility, hummingbirds

\section{Introduction}

Distyly is found in ca. 27 angiosperm families and it is understood as a mechanism to promote pollination and cross fertilization (Darwin 1877; Barrett et al. 2000b; Li \& Johnston 2001). Distylous plants present individuals with flowers with long styles and short stamens, the pin morph, and individuals with flowers with short styles and long stamens, the thrum morph (Ganders 1979). The ratio between morphs in populations is commonly 1:1, an equilibrium denominated isoplethy (Ganders 1979; Sobrevila et al. 1983). Together with the floral dimorphism, distylous species usually have a diallelic sporophytic self-incompatibility system, in such a way that fruit set arises only from pollination between floral morphs (Barret \& Richards 1990). Genetic control of the self-incompatibility mechanism and floral dimorphism seems to be determined by a heteroallelic "supergene", comprising a tightly linked series of loci (Ganders 1979; Gibbs 1990).
Besides the position of reproductive structure, the floral morphs may also exhibit differences in stigma morphology, pollen grains, corolla size and nectar production (Johnston 1952; Levin 1968, Ganders 1976; Ornduff 1976; Ganders 1979; Barrett 1992; Dulberger 1992; Castro et al. 2004; Castro \& Oliveira 2002; Ornelas et al. 2004; Teixeira \& Machado 2004a). Little is yet known of the origin and selective pressures that lead to these ancillary differences between floral morphs, but it is believed that they also affect the pollen flow between morphs (Feinsinger \& Busby 1987; Stone 1995; Lau \& Bosque 2003).

The family Rubiaceae has the largest number of distylous genera and species among the families for which the polymorphism has been reported (Ganders 1979; Barrett \& Richards 1990). It is the fourth largest family of the angiosperms, with ca. 650 genera and 12,000 species of Pantropical distribution, and the largest family in the

\footnotetext{
1 Universidade Federal de Uberlândia, Instituto de Biologia, Programa de Pós-graduação em Ecologia e Conservação de Recursos Naturais, Uberlândia, MG, Brasil

2 Universidade de Brasília, Programa de Pós-graduação em Botânica. Instituto de Ciências Biológicas, Brasília, DF, Brasil

3 Universidade Federal de Goiás, Departamento de Ciências Biológicas, Catalão, GO, Brasil

${ }^{4}$ Author for correspondence: poliveira@ufu.br
} 
Neotropics, with some 200 genera and 1500 species (Delprete 2004). It is also one of the main families of the Brazilian flora, with ca. 130 genera and 1500 species (Souza \& Lorenzi 2005). In the Cerrado Biome, the Neotropical Savannas in Central Brazil, it is considered the seventh most species-rich family, with at least 376 species (Mendonça et al. 2008), among which ca. $41 \%$ are distylous species (Consolaro 2008). Palicourea has ca. 200 species and distyly is a very common, basal feature of the genus (Vuilleumier 1967; Taylor 1997). Its odorless flowers have a bright colored tubular corolla and are mainly pollinated by hummingbirds (Taylor 1997). Palicourea rigida H. B. \& K. is a widely distributed species, occurring in more than $37 \%$ of the cerrado areas studied so far (Ribeiro \& Walter 2008; Ratter et al. 2003), possibly the most common Palicourea species of the Brazilian cerrados.

Cerrado is the second largest biome in Brazil, a complex of plant formations with ecological and physiognomic similarities with other savanna areas in the Neotropics, Africa and Australia, with forest, open savanna and grassland areas (Ribeiro \& Walter 2008). Its flora is characteristic and differentiated, although it shares some genera with surrounding biomes, and is directly or indirectly affected by climate, soil and anthropic disturbance, especially fire frequency (Ribeiro \& Walter 2008). The effect of these factors appears in the structure, spatial distribution and floristic composition (Oliveira 2008; Ribeiro \& Walter 2008).

Recent works on the Cerrado biome have shown variation and anomalies in the features of distylous plant populations (Coelho \& Barbosa 2003; Consolaro et al. 2005; Toledo et al. 2007; Consolaro et al. 2009). In this sense, our work aimed to characterize the floral biology of $P$. rigida and to study different populations comparing morph distribution and ancillary features associated with distyly.

\section{Materials and methods}

Period and study areas - The data were collected during the flowering season between 1993 and 1995 (PI), and between 2005 and 2007 (PII). The study during PI was carried out at the Água Limpa Farm (FAL) (1557’S; $\left.47^{\circ} 55^{\prime} \mathrm{W}\right)$, Brasília, DF, a research area of 4,500 ha belonging to the Universidade de Brasília. The second study period (PII) took place at Serra de Caldas Novas State Park (PESCAN) and in the Clube de Caça e Pesca Itororó de Uberlândia (CCPIU). PESCAN (17\%43'S; 48 $40^{\circ} \mathrm{W}$ ) comprises 12,500 ha in Caldas Novas, Goias and Rio Quente, Goias and CCPIU (18 $55^{\prime}$ S' $48^{\circ} 17^{\prime} \mathrm{W}$ ) is a private 640-hectare reserve southwest of Uberlândia, Minas Gerais. The areas are dominated by cerrado plant formations.

Species studied - Palicourea rigida is a shrub or treelet with characteristic thick bark deeply cleft into rectangular blocks. It is commonly known as "batecaixa" and "gritadeira" due to its rigid, coriaceous leaves (Silva-Júnior 2005). It has terminal thyrsoid inflorescences with zygomorphic flowers (Robbrecht 1988). It is widely distributed in the savannas of South America (Taylor 1997), and frequent in the open cerrado and cerradões (denser woodlands) in the states of Bahia, Goiás, Minas Gerais, Mato Grosso, Mato Grosso do Sul, Paraná, São Paulo, Tocantins and Distrito Federal (Silva-Júnior 2005). Floral biology - Anthesis, flower life-span, stigmatic receptivity and pollen release were observed in the field (a minimum of 20 flowers each study period) and in branches brought to the laboratory and kept in vases with water. Stigma receptivity was tested with 3\% hydrogen peroxide (Kearns \& Inouye 1993).
Phenology - Quantitative phenodynamic data was collected only for flowering during PI. The beginning, peak (more than fifty percent of open flowers) and end of the flowering period were recorded for 50 individuals. More general phenological observations were done during PII in order to determine if there were marked differences between populations and study periods (69 individuals at PESCAN and 100 at CCPIU).

Population features and isoplethy - In order to describe basic population structure and to estimate isoplethy, blooming plants were sampled and marked (50 plants at FAL, 69 at PESCAN and 100 at CCPIU, the same plants used for phenological observations). The number of inflorescences per plant was counted for the FAL and CCPIU populations, while height and density were estimated for the PESCAN and CCPIU populations only. Density was estimated using the nearest neighbor method (Brower \& Zar 1984), with the distance between individuals obtained by GPS coordinates. Density was later estimated for the FAL population using the individuals mapped in a 0.3328 ha area. The floral morph of each individual was determined and the morph ratio was calculated for each population. Isoplethy $(1: 1 \mathrm{morph}$ ratio equilibrium) was tested in each case.

Floral morphometry and nectar - Some flowers were collected at random and fixed in $70 \%$ ethanol for measurements in the laboratory (20 flowers for each floral morph, from at least 5 individuals of each morph) and other flowers were measured directly in the field (28 pin flowers and 14 thrum flowers in PI). All flower measurements were carried out using a digital pachymeter (error $0.01 \mathrm{~mm}$ ), under stereomicroscope whenever necessary. The following structures were measured: corolla length and diameter, stamen and anther length, and style and stigma length.

Pollen size and morphology were investigated for each morph using both light and scanning electron microscope (SEM). The latter was used only in PI ( 20 pollen grains from thrum and 24 from pin flowers) to detail pollen morphology. The material for SEM observations was prepared using anthers from fresh flowers directly fixed in Osmium tetroxide vapor during 24 hours (Smith \& Tiedt 1991). SEM analyses were used only for pollen measurements. The presence of lipids on the pollen grains was tested using Sudan IV (Johansen 1940).

The amount of pollen was estimated by counting the total number of pollen grains in one anther per flower. The anthers were extracted from floral buds the day before anthesis and fixed in $70 \%$ alcohol during the PI only (10 floral buds for each morph). The pollen/ovule ratio (sensu Cruden 1977) was calculated from these estimates. Pollen viability was estimated from flowers of different periods after anthesis by using Alexander's stain (modified as in Dafni 1992).

Nectar collection was done at the end of the morning in previously bagged fresh flowers. The volume was measured using glass micropipettes or microseringes and concentration was determined using a hand refractometer. Five to seven flowers from each morph were used during PI, and 50 thrum flowers and 43 pin flowers were used during PII, three to five flowers from 10 individuals of each morph.

Breeding system - Controlled hand pollination tests were carried out in order to determine the breeding system using plants at FAL during PI. The index of self-incompatibility (ISI) was calculated by using fruit-set results from those tests, as the fruit-set ratio between self- and between morph crosspollination tests (sensu Bullock 1985). Flowers on the day before anthesis or freshly open were marked with threads of different colors to identify treatments, and were then isolated using nylon mesh bags. The tests followed the same protocol adopted for breeding system studies in other distylous species of Rubiaceae (Bawa \& Beach 1983): hand self-pollination (flower pollinated with its own pollen) or cross-pollination (flower pollinated with pollen from other plants, either from the same morph - intramorph or illegitimate pollination - or from the other morph - between morph or legitimate pollination). Some flowers were left untouched in order to test spontaneous self-pollination (flowers bagged before anthesis).

At CCPIU (during PII), legitimate and illegitimate cross pollination was done using previously bagged flowers in order to observe pollen-tube growth. Hand pollinated flowers were collected six hours after pollination and fixed in $70 \%$ alcohol. Five pistils of each treatment and morph were analyzed (from five different plants) using fluorescence microscopy technique (Martin 1959).

In order to estimate the efficiency of natural pollination, 67 inflorescences of thrum individuals (12,646 flowers) and 91 of pin individuals $(13,658$ flowers $)$ were marked in the first flowering season in 
PI (1993) and 61 inflorescences of thrum individuals (10,353 flowers) and 86 of pin individuals (10,243 flowers) during the second flowering season in PI (1994). During PII, 120 floral buds from each morph were marked at PESCAN and 60 at CCPIU (five flowers per inflorescence and two to four inflorescences per individual). Also during PII, 12 inflorescences for each morph were analyzed in order to count fruits developed after natural pollination (a total of 2,485 flowers for thrum and 3,252 for pin at PESCAN, and 2,247 flowers for thrum and 2,319 for pin at CCPIU). This analysis could be used for $P$. rigida because the ovary and nectary disc of non-fertilized flowers persist up to inflorescence abscission or leave scars that can be used to count flowers. Developed fruits and non-fertilized flowers were counted 30 or 40 days after flowering (fruit development can be assessed ca. 10 days after anthesis).

In PII, pollen tube growth under fluorescence microscopy (Martin 1959) was also used to estimate natural pollination success. Flowers from both morphs were collected and fixed in $70 \%$ alcohol at the end of anthesis. The amount of pollen grains germinating on the stigma and pollen tubes effectively growing along the style were quantified ( 30 flowers for each morph in each population, three to five flowers per individual).

Flower visitors - The pollinators were determined according to flower architecture, morphology and behavior of the visitors for each study period and population. The main pollinators were the most frequent pollinators during the study period, appearing at most of the observation sessions and throughout the flowering season. Additional pollinators were less frequent, appearing in less than half of the observation sessions and sometimes only during part of the flowering season. As much as possible, visitors were photographed and/or captured for identification by specialists. Although flowers were visited also by insects of various groups, observations were restricted to hummingbirds and bees.

Statistical analysis - Morphometric comparisons between flowers were done using one-factor ANOVA (morph). They were done using ranked values whenever the data did not reach normality. Student t-test was used to compare pollen size and nectar measurements between floral morphs. Fisher's exact test for chi-square approximation was applied to test isoplethy between floral morphs in each population, verify differences in reproductive success between flower morphs, and natural fruit set in marked inflorescences between populations. All analyses were done using the program Statistica 6.0 (StatSoft Inc. 2001).

\section{Results}

Floral biology - Flowers of Palicourea rigida are presented in dense terminal inflorescences, pedunculate cymose thyrses arising between a pair of leaves. The development from bud primordia to anthesis of the first flowers took ca. 60 days. The flowers are zygomorphous, dichlamydeous and hermaphrodite. The ovary is inferior, mostly bilocular with a basally fixed ovule at each locus. Above the ovary there is a conspicuous nectary disc which surrounds the base of the style. The stigma is of the dry papillate type (sensu Heslop-Harrison \& Shivanna 1977), usually bifid, but more rarely trifid. The form and size of the stigma differed markedly between the morphs. The androecium is formed by five stamens adnate to the corolla by two thirds of their length. Anthers are long, dorsifixed, bitecae, introrse with longitudinal dehiscence. The hairy hypanthium has five discrete lacinea. The corolla is tubular with a gibbous base and an internal ring of longer hairs which somewhat protects access to the nectar. The color of the corolla varies from yellow to reddish.

Anthesis began before dawn, between 3 and 5 o'clock. Flower duration was around 24 hours, with most flowers wilting, darkening and falling off the morning of the second day. In some thrum flowers anther dehiscence occurs before flower opening, leaving the stigma, still unreceptive, covered with pollen. In pin flowers the stigma is receptive before anthesis and the pollen is released a bit later. The test with $\mathrm{H}_{2} \mathrm{O}_{2}$ indicated that receptivity continues throughout the day. Sometimes it was possible to observe a slight contraction of the stigmatic lobes after pollen deposition.

Phenology - During the study, the populations presented a single annual flowering peak in the rainy season (Figure 1), but it was common to observe extemporaneous flowering in other periods of the year (Silva 1995). The flowering period in Brasília (PI) in 1993 began at the end of September, peaked in mid-November and finished at the end of January 1994. The next blooming season began in mid-September 1994, peaked again in November and continued until March 1995. There were no marked differences between morphs in phenodynamics but there were differences between years in PI (Figure 1). In the study areas during PII, both in 2005 and 2006, flowering at PESCAN began in September while at CCPIU it began only in November. In all cases flowering ended in March of the following year.

Population characteristics and isoplethy - The density of reproductive individuals of Palicourea rigida during PI was 150.24 individuals/ha and in PII was 119 individuals. ha $^{-1}$ for PESCAN and 182.61 individuals.ha ${ }^{-1}$ for CCPIU. The height of the individuals, estimated without distinction between morphs, was $2.12 \pm 0.52 \mathrm{~m}$ for PESCAN and $1.14 \pm 0.27 \mathrm{~m}$ for CCPIU. Reproductive effort, estimated as the number of inflorescences per individual, did not vary between morphs. In the census of the FAL population (PI), thrum individuals produced an average of $8.00 \pm 7.00$ inflorescences and significantly more than the pin individuals which produced $6.00 \pm 4.00$ inflorescences $(p<0.05)$. At CCPIU (PII), thrum individuals produced an average of 4.82 \pm 3.28 inflorescences while the pin ones produced $5.77 \pm$ 5.75 inflorescences $(U=1181.0 ; P=0.65)$.

In the FAL population (PI), the ratio between morphs was significantly different from the 1:1 equilibrium, with 14 thrum and 28 pin individuals $\left(\chi^{2}=4.66 ; P=0.04\right)$ in 1993 and 15 thrum and 28 pin individuals $\left(\chi^{2}=3.93 ; P=0.0474\right)$ in 1994. At PESCAN (PII), the population was isoplethic, with 35 thrum and 34 pin individuals $\left(\chi^{2}=0.014 ; P=0.9042\right)$, as was the population of CCPIU (PII), with 59 thrum and 41 pin individuals $\left(\chi^{2}=3.24 ; P=0.0719\right)$.

Floral morphometry and nectar - The flowers of the FAL population (PI) showed no statistical difference in corolla length and diameter between morphs (Table 1). The thrum flowers of the population at PESCAN (PII) presented corolla significantly longer than the pin flowers $(U=782.50 ; P<0.05)$, but they did not differ in diameter $(U=1239.00 ; P>0.05)$ (Table 1). At CCPIU (PII), the flowers were different both in corolla length $(U=93.50 ; P<0.0001)$ and diameter $(U=535.50 ; P<0.0001)$, the thrum flowers larger than the pin flowers (Table 1).

Both in the PI and PII, the height of the stigma was statistically larger in the pin flower and the height of the anthers and stigmatic lobe length were larger in the 


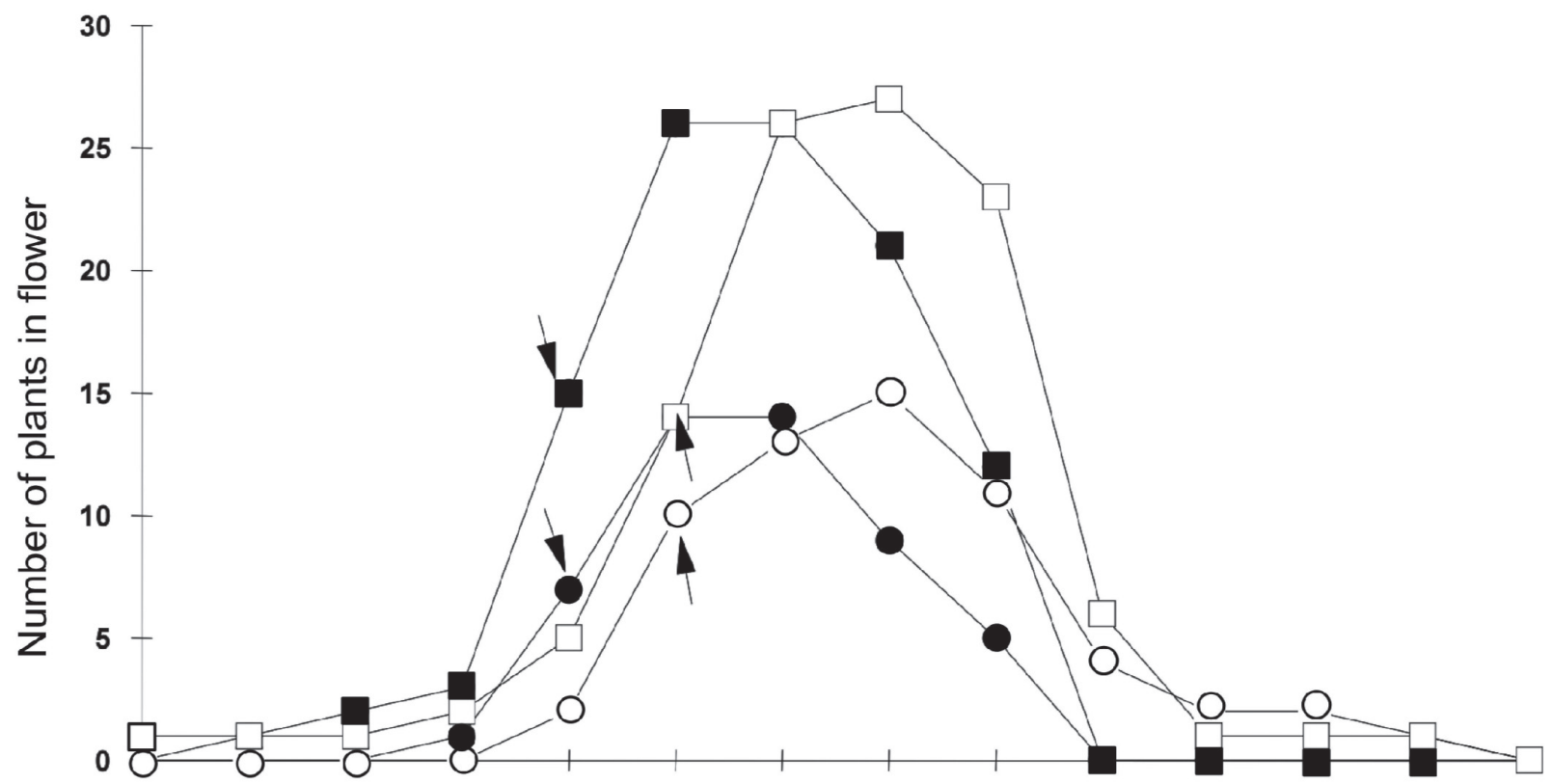

15-Sep 30-Sep 15-Oct 30-Oct 15-Nov 30-Nov 15-Dec 30-Dec 15-Jan 30-Jan 15-Feb 28-Feb 15-Mar 30Mar

Flowering period

Figure 1. Flowering phenology of of thrum $(\mathrm{O})$ and pin $(\square)$ plants of Palicourea rigida H. B. \& K. (Rubiaceae) marked and followed in the Fazenda Água Limpa (FAL) in 1993 (dark symbols) and 1994 (open symbols). Arrows indicate the beginning of flowering and peaks (more than 50\% of the plants flowering).

Table 1. Floral morphometrics of thrum and pin flowers of Palicourea rigida H.B. \& K. (Rubiaceae) in the Fazenda Água Limpa (FAL). Parque Estadual da Serra de Caldas Novas (PESCAN) and Clube de Caça e Pesca Itororó de Uberlândia (CCPIU) (cm, mean \pm standard deviation). Means followed by different letters indicate statistical differences at $\mathrm{P}<0,05$ between morphs in each population, $\mathrm{n}=$ number of flowers, $\mathrm{F}$ and $\mathrm{P}$ values of ANOVA analysis for comparison between morphs.

\begin{tabular}{|c|c|c|c|c|c|c|}
\hline \multirow{4}{*}{$\begin{array}{l}\text { Measured } \\
\text { items }\end{array}$} & \multicolumn{2}{|c|}{ FAL } & \multicolumn{2}{|c|}{ PESCAN } & \multicolumn{2}{|c|}{ CCPIU } \\
\hline & Thrum & Pin & Thrum & Pin & Thrum & Pin \\
\hline & $\mathrm{n}=14$ & $\mathrm{n}=28$ & $\mathrm{n}=20$ & $\mathrm{n}=20$ & $\mathrm{n}=20$ & $\mathrm{n}=20$ \\
\hline & \multicolumn{2}{|c|}{$F=1049,65$} & \multicolumn{2}{|c|}{$F=1015,44$} & \multicolumn{2}{|c|}{$F=1124,16$} \\
\hline Corolla length & $1,86 \pm 0,30 \mathrm{a}$ & $1,83 \pm 1,34 \mathrm{a}$ & $1,92 \pm 0,1 \mathrm{a}$ & $1,73 \pm 0,14 \mathrm{~b}$ & $1,71 \pm 0,09 \mathrm{a}$ & $1,7 \pm 0,1 \mathrm{a}$ \\
\hline Corolla diameter & $0,34 \pm 0,30 \mathrm{a}$ & $0,33 \pm 0,30 \mathrm{a}$ & $0,45 \pm 0,03 \mathrm{a}$ & $0,4 \pm 0,03 \mathrm{a}$ & $0,36 \pm 0,03 \mathrm{a}$ & $0,38 \pm 0,03 \mathrm{a}$ \\
\hline Stigma height & $1,5 \pm 1,44 \mathrm{a}$ & $1,88 \pm 1,77 \mathrm{~b}$ & $1,28 \pm 0,06 \mathrm{a}$ & $1,77 \pm 0,15 b$ & $1,64 \pm 0,06 \mathrm{a}$ & $1,7 \pm 0,07 b$ \\
\hline Anther height & $1,71 \pm 1,14 \mathrm{a}$ & $1,24 \pm 1,06 b$ & $1,92 \pm 0,04 \mathrm{a}$ & $1,36 \pm 0,19 b$ & $1,64 \pm 0,16 \mathrm{a}$ & $1,3 \pm 0,14 b$ \\
\hline Stigma length* & $0,36 \pm 0,69 \mathrm{a}$ & $0,13 \pm 0,28 b$ & $0,46 \pm 0,08 \mathrm{a}$ & $0,13 \pm 0,02 b$ & $0,46 \pm 0,06 \mathrm{a}$ & $0,16 \pm 0,02 b$ \\
\hline Anther length** & $0,34 \pm 0,38 \mathrm{a}$ & $0,33 \pm 0,41 \mathrm{a}$ & $0,45 \pm 0,04 \mathrm{a}$ & $0,4 \pm 0,02 \mathrm{a}$ & $0,42 \pm 0,03 \mathrm{a}$ & $0,38 \pm 0,02 \mathrm{a}$ \\
\hline Nectar volume $(\mathrm{mL})(\mathrm{n}=50)$ & $17,00 \pm 8,00 \mathrm{a}$ & $12,00 \pm 6,00 \mathrm{a}$ & $7,88 \pm 4,58 \mathrm{a}$ & $6,89 \pm 2,61 \mathrm{a}$ & $11,79 \pm 3,42 \mathrm{a}$ & $8,71 \pm 3,22 b$ \\
\hline Nectar Concentration $(\%)(n=50)$ & $19,70 \pm 1,60 \mathrm{a}$ & $21,10 \pm 1,30 \mathrm{a}$ & $20,46 \pm 2,17 \mathrm{a}$ & $21,92 \pm 1,89 b$ & $20,40 \pm 3,10 \mathrm{a}$ & $21,10 \pm 2,41 \mathrm{a}$ \\
\hline
\end{tabular}

* 1 stigma lobe/flower. ** 1 anther/flower

thrum flowers (Figures 2, 3 and 4), characterizing distyly. Measurements indicated reciprocal herkogamy (Table 1 and Figure 2) but we did not test it directly. The length of the anthers did not differ between morphs in the FAL (PI), but it was larger in thrum flowers both at PESCAN $(U=74.00$; $P<0.001)$ and CCPIU $(U=76.00 ; P<0.001)$ (Table 1).

Nectar production began at flower opening and continued during the day, accumulating in the gibbous base of the corolla but could reach most of the length of the corolla tube.
In the FAL (PI) there was no difference between morphs neither for nectar volume nor sugar content. In the population at PESCAN (PII) there was no difference between morphs for nectar volume $(t=-1.32 ; P>0.05)$. However, pin flowers produced a significantly more concentrated nectar than the thrum flowers $(t=3.51 ; P<0.05)$. At CCPIU (PII), thrum flowers produced significantly larger volume of nectar than pin flowers $(t=-3.13 ; P=0.0031)$, but there was no difference in sugar concentration $(t=0.85 ; P=0.4002)$. 

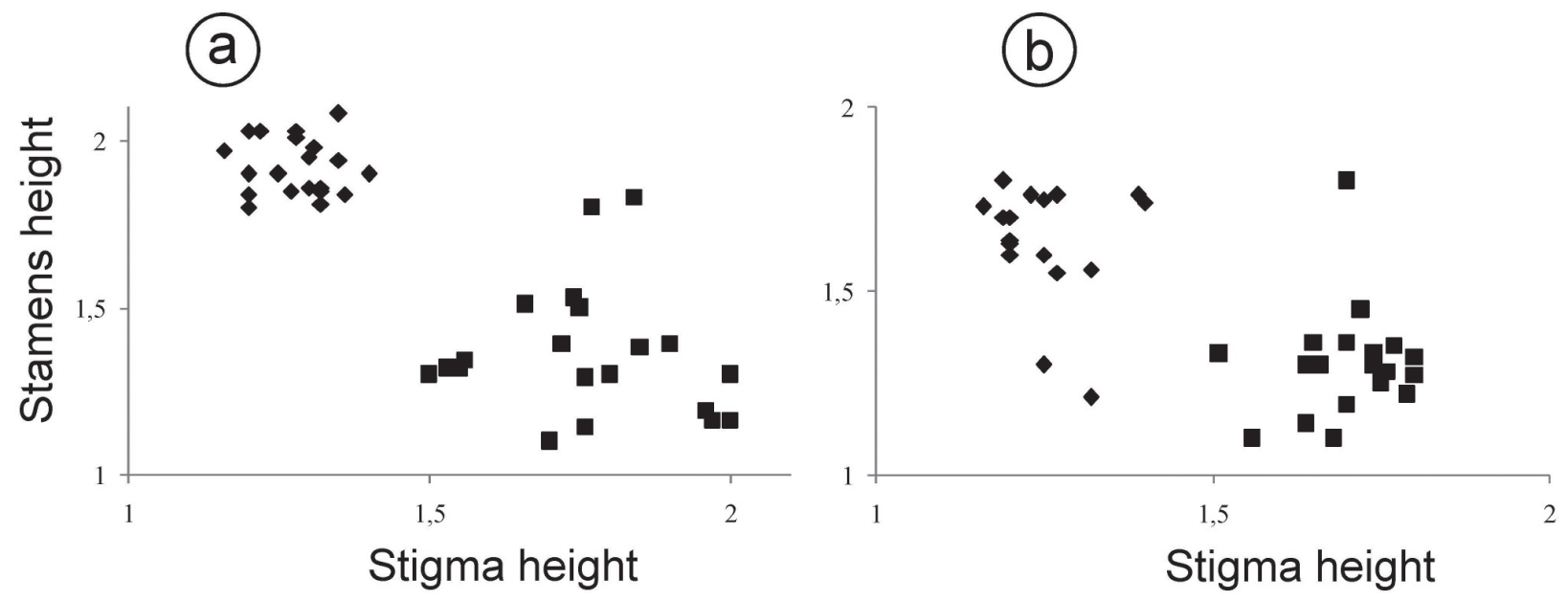

Figure 2. Relationship between size of pistils and stamens (cm) of thrum $(\star)$ and pin flowers $(\mathbf{a})$ of Palicourea rigida H. B. \& K. (Rubiaceae) in the Parque Estadual da Serra de Caldas Novas (PESCAN) (a) and Clube Caça e Pesca Itororó de Uberlândia (CCPIU) (b).

Palicourea rigida produced spherical, non-aperturate, pollen grains released in irregular clusters, adhered by a lipid substance indicated by the Sudan IV. There was no clear dimorphism between pollen grains of each morph, but measurements showed statistical differences in pollen diameter $(54.2 \mu \mathrm{m} \pm 2.6, \mathrm{n}=20$ for thrum and $51 \mu \mathrm{m} \pm$ $4.6, \mathrm{n}=24$ for pin; $P<0.01)$. Viability tests indicated high viability in freshly open flowers but a quick loss of viability 24 hours after anthesis. The average number of pollen grains produced by pin flowers was 2600 and for thrum flowers was 2850 . The pollen/ovule ratio was $1305.0 \pm 183.3(\mathrm{n}=10)$ for thrum and $1425.7 \pm 289.3$ $(\mathrm{n}=10)$ for pin flowers, with no statistical difference between morphs $(P<0.01)$.

Breeding system - The data obtained from hand pollination tests carried out in the FAL (PI) showed that $P$. rigida is a self-incompatible species without autonomous apomixis (Table 2). Most self-pollinated flowers did not produce fruits and the ISI was 0.06 for the pin morph in 1994 and zero in 1995. Some fruits were also formed from spontaneous selfing, but were very few when compared to hand-cross and natural pollination. About 10 days after pollination, it was possible to observed hypanthium thickening and fruit development. Fruit growth was slow, taking a mean of 75 days to reach maturation. Ripe fruits were observed from February on in all study periods and sites.

The efficiency of fruit-set after natural pollination varied widely during the PI. In 1993, thrum plants of the FAL population presented fruit-set of $22.20 \%$ and the pin plants $14.70 \%$. In 1994, thrum plants had a fruit-set of $30.04 \%$ while pin plants had $39.90 \%$. During PII, the analysis of fruit set from marked floral buds did not reveal significant differences between morphs. At PESCAN, thrum plants had $41.70 \%$ fruit-set and pin plants $31.80 \%(t=1.56 ; P>0.05)$. At CCPIU, fruit-set was $52.33 \%$ for thrum plants and $56.66 \%$ for pin plants $(t=0.37 ; P>0.05)$.
The fruit-set results obtained from inflorescence surveys, using the scars left by the flowers and fruits effectively developed, did not show between-morph differences either. In PESCAN (PII), thrum plants had a fruit-set of $51.11 \pm 13.35 \%$, while pin plants had $44.08 \pm$ $11.76 \%(t=-1.37 ; P=0.18)$. At CCPIU (PII), thrum plants had $51.33 \pm 13.16 \%$ while pin plants had $43.49 \pm 14.45$ $\%$ fruit set $(t=-1.39 ; P=0.18)$.

Pollen tube growth analysis after natural pollination in PII showed large pollen load in most pistils and in all of them we observed germinating pollen grains and pollen tubes growing along the style. Thrum flowers presented larger amounts of pollen tubes than pin flowers in both populations and only some pin flowers at CCPIU presented pistils with less than 10 pollen grains germinating. Thrum flowers at PESCAN presented $86.70 \%$ of the analyzed pistils with more than 50 germinating pollen grains while pin flowers presented more than $40 \%$ of the pistils with that amount of pollen grains. At CCPIU, $96.70 \%$ of thrum flowers had more than 50 pollen grains germinating on the stigma while pin flowers presented more than $30 \%$ of the stigmas with that amount of pollen grains.

Pistils of thrum flowers after self-pollination and illegitimate cross-pollination presented pollen tubes which appeared fragile (enlarged and curved) and grew relatively short into the stigma (Figure 5 and 6). In self-pollinated pistils of pin flowers, pollen tubes presented bright fluorescence, many callose plugs, enlarged portions and apparent branching (Figure 7), and larger diameter than the tubes observed in legitimate cross-pollinated pistils. These self pollen tubes grew along the style and seemed to be blocked at the base, before reaching the ovary (Figure 8), forming callose plugs (Figure 9). The pollen tubes formed in illegitimate crosspollination pistils were also observed along the style but did not reach the ovary. After legitimate pollination in both 
Table 2. Data obtained from the experimental pollination tests of Palicourea rigida H.B. \& K. (Rubiaceae) carried out in the Fazenda Água Limpa (FAL) in 1993 and 1994. T: thrum, $\mathrm{P}:$ pin, $\mathrm{n}=$ number of plants, $\mathrm{fl}=$ number of pollinated flowers, $\mathrm{fr}=$ number of fruits produced, $\%$ of fruits).

\begin{tabular}{|c|c|c|c|c|c|}
\hline \multirow{2}{*}{ Tests } & & \multicolumn{2}{|c|}{1993} & \multicolumn{2}{|c|}{1994} \\
\hline & & $\mathrm{fr} / \mathrm{fl}$ & $\%$ & $\mathrm{fr} / \mathrm{fl}$ & $\%$ \\
\hline \multirow{2}{*}{ Spontaneous self-pollination } & $\mathrm{T}$ & $24 / 1979$ & $1,2(n=9)$ & $5 / 781$ & $0,6(n=2)$ \\
\hline & $\mathrm{P}$ & $16 / 2117$ & $0,8(\mathrm{n}=10)$ & $79 / 2023$ & $4,0(\mathrm{n}=8)$ \\
\hline \multirow{2}{*}{ Hand self-pollination } & $\mathrm{T}$ & $0 / 20$ & $0(\mathrm{n}=4)$ & $0 / 27$ & $0(\mathrm{n}=5)$ \\
\hline & $\mathrm{P}$ & $0 / 28$ & $0(\mathrm{n}=5)$ & $2 / 24$ & $8,0(\mathrm{n}=5)$ \\
\hline \multirow{2}{*}{ Legitimate cross-pollination } & $\mathrm{T}$ & $9 / 17$ & $52,9(\mathrm{n}=4)$ & $17 / 45$ & $31,1(\mathrm{n}=3)$ \\
\hline & $\mathrm{P}$ & $1 / 6$ & $16,7(n=2)$ & $32 / 40$ & $80,0(n=3)$ \\
\hline \multirow{2}{*}{ Illegitimate cross-pollination } & $\mathrm{T}$ & & & $0 / 24$ & $0(n=4)$ \\
\hline & $\mathrm{P}$ & $0 / 3$ & $0(\mathrm{n}=1)$ & $1 / 20$ & $5,0(\mathrm{n}=4)$ \\
\hline \multirow{2}{*}{ Agamospermy } & $\mathrm{T}$ & & & $0 / 20$ & $0(n=4)$ \\
\hline & $\mathrm{P}$ & $0 / 8$ & $0(\mathrm{n}=2)$ & $0 / 26$ & $0(n=6)$ \\
\hline
\end{tabular}

morphs, pollen tubes grew without problems and were observed in the ovary (Figures 10 and 11).

Floral visitors $-P$. rigida flowers were visited by 11 hummingbird species and 21 species of insects of different orders (table 3). In FAL, Colibri serrirostris (Figure 12) was the most frequent flower visitor and was considered the main pollinator. It showed clear territorial behavior, although it visited individuals of different morphs in the defended territory. C. serrirostris collected nectar sequentially in every open flower throughout the day (6:00 - 18:00 h) at intervals that varied between 10 and 30 minutes (longer intervals during the warmer parts of the day). A similar situation was observed at PESCAN and CCPIU where Eupetomena macroura (Figure 13) was the most frequent visitor and, despite its territorial behavior, visited plants of different morphs and was considered the main pollinator.

Another nine species of hummingbirds visited $P$. rigida flowers and appeared, in some cases, to have well defined foraging routes. However, it was not possible to characterize clearly this foraging pattern. These hummingbirds were less frequent and visited quickly, though legitimately, some flowers per bout, being considered additional pollinators.

Bees were observed constantly on $P$. rigida flowers (Table 3), collecting nectar or pollen but were not always legitimate pollinators. They were considered additional pollinators only when their size and behavior made possible the contact with anthers and stigma. In many cases, floral resources, especially nectar, were collected with the bee inserting only part of its body or the proboscis inside the corolla tube, and eventually touching the stigma or stamens. However, some species pillaged nectar by perforating the corolla base or using apertures made by other visitors. Analysis of the collected specimens showed very small amounts of pollen on the body, except on Bombus morio workers, which had a lot of pollen adhered to the hairs on the thorax and accumulated on the corbiculae.

\section{Discussion}

The $P$. rigida populations studied differed in some structural aspects, such as density and height of individuals, but the values are similar to the values described for populations in other Neotropical savannas, as the 187 individuals/ha found in a population in Venezuela (Wütherich et al. 2001). They presented density much higher than the 34 individuals/ha cited as an average density for $P$. rigida (Silva-Júnior 2005), probably because this average is based on phytosociological surveys limited to individuals over $10 \mathrm{~cm} \mathrm{dbh}$. Despite the differences in density and size, the populations studied did not present any distyly anomaly that could be associated with these structural differences. Neither were these structural differences related clearly to conservation status or history of the study areas.

The flowering pattern for the populations studied is of the annual extended type, since there was a single main flowering event each year with over five months duration (Newstrom et al. 1994). Actually, in 1993 the flowering period was less than five months and the pattern in this case would be classified as annual intermediate. However, since the difference between flowering pattern types is less than a month and during the other years the period was longer, species flowering phenology may be better described as annual extended. Observed differences between flowering peaks in PI and small differences in the beginning and duration of flowering periods are common in tropical environment and especially in a widely distributed species as $P$. rigida.

The occurrence of extemporaneous flowering, as in PI, is characteristic of subannual flowering (Newstrom et al. 1994) and would explain the presence of herbarium sheets with flowering specimens most of the year (Silva 1995). This type of flowering strategy may benefit the plants, since flowers and fruits will be available most of the year. This has been cited for other Cerrado plants (Oliveira \& Gibbs 2000). However, these phenological asynchronies should be treated 


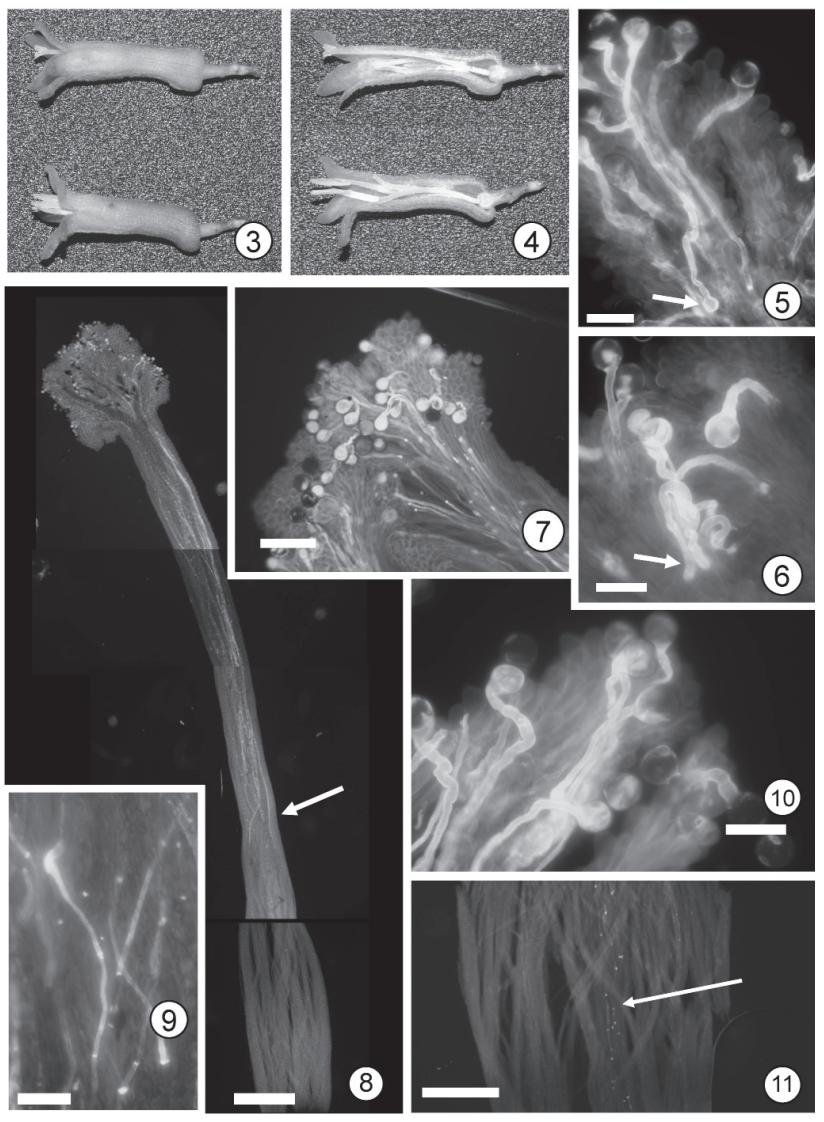

Figures 3-11. Flower morphology and pollen tube growth in Palicourea rigida $\mathrm{H}$. B. \& K. (Rubiaceae) from the Fazenda Água Limpa (FAL), Parque Estadual da Serra de Caldas Novas (PESCAN) and Clube Caça e Pesca Itororó de Uberlândia (CCPIU). 3. Pin flower (above) and thrum flower (bellow). 4. Longitudinal sections of the same flowers showing the differences between pin and thrum morphs. 5. Epifluorescence photomicrography showing pollen germination and pollen tube growth on the stigma of a self-pollinated pistil of a thrum flower. 6. Similar to figure 5, but an illegitimate pollinated pistil of a thrum flower. Note in figures 5 and 6 the callose rich vesicles that seem to be associated with incompatibility reaction (arrows). 7. Epifluorescence photomicrography showing pollen tube growth of the stigma of a self-pollinated pistil of a pin flower. 8 . Epifluorescence photomicrography mosaic of pin flower self-pollinated pistil showing pollen tube arresting at the second third of the style (arrow). 9. Details of anomalous callose plugs formed at the tip of pollen tubes after illegitimate pollination in a pin flower. 10. Pollen tube germination and growth in a legitimate pollinated pistil of a pin flower. 11. Pollen tube growing normally down to the base of the style of a legitimate pollinated pin flower (arrow). All pistils fixed six hours after hand pollinations. Figures 5, 6 and 10 scale bar $=100 \mu \mathrm{m} ; 7$ and 9 scale bar $=200 \mu \mathrm{m} ; 8$ and 11 scale bar $=1000 \mu \mathrm{m}$.

with caution since they do not occur every year and are not well understood yet (Newstrom et al. 1994).

The isoplethy found in the populations studied during PII contrasted with the anisoplethy recorded for the FAL population. But it should be noted that the number of individuals in that area was much smaller than those surveyed at PESCAN and CCPIU, and the anisoplethy may be result of this limited sample. In another survey carried out in the Distrito Federal, in an area near to the FAL, isoplethic populations were recorded for different distylous Rubiaceae, including $P$. rigida (H.N. Consolaro pers. obs.). Smaller populations of Hottonia palustris, a distylous European species, tended to present greater deviation from the 1:1 morph ratio than larger populations (Brys et al. 2007).

Studies with Palicourea padifolia (Ree 1997; Ornelas et al. 2004) and P. fendleri (Sobrevila et al. 1983) showed isoplethic populations. In Brazil, specifically in an Atlantic forest remnant, a $P$. longepedunculata population was isoplethic while $P$. marcgravii was anisoplethic (Pereira et al. 2006). In the Cerrado, $P$. coriacea and $P$. macrobotrys presented deviation from the equilibrium morph ratio, while $P$. officinalis and $P$. marcgravii were isoplethic (Consolaro et al. 2009). Apparently, the primary mechanism maintaining equilibrium morph ratio is density dependent, favored in populations where there are higher numbers of legitimate cross-pollinations than illegitimate ones (Barrett et al. 2000a).

Anisoplethy may be also caused by vegetative multiplication and loss of intramorph self-incompatibility (Barrett 1992). Breakdown of self-incompatibility and rising and dominance of homostylous individuals have been reported for Rubiaceae species in forest habitats inside the Cerrado biome and may be associated with disturbance and habitat fragmentation (Coelho \& Barbosa 2003; Consolaro et al. 2009). Initial stages of functional distyly loss seem to be associated with changes in reciprocal herkogamy (VallejoMarín \& Barrett 2009), especially in the genus Palicourea (Consolaro et al. 2009). But the reciprocal herkogamy seems to be present in the studied populations of $P$. rigida, depite the ancillary differences between flower morphs. Larger structures in the thrum flowers, as stigmatic lobes and anthers, are common in distylous species, especially in the Rubiaceae (Baker 1956; Ornduff 1980, Sobrevila et al. 1983; Murray 1990; Dulberger 1992; Richards \& Koptur 1993; Castro \& Araújo 2004; Castro et al. 2004; Coelho \& Barbosa 2004; Rossi et al. 2005; Pereira et al. 2006). However, distylous species in other families present larger stigmatic lobes in pin flowers (Ornduff 1971; Dulberger 1992). These ancillary differences have been associated with the efficiency of legitimate pollinations. Pollen grains and stigmatic surface dimorphism would reduce or avoid illegitimate cross pollination and its reproductive consequences (Vuilleumier 1967; Ganders 1979; Barrett 1992). However, these trends on ancillary floral features cannot be generalized since, even for the Rubiaceae, there are distylous species without either pollen or stigmatic lobe dimorphism (Castro et al. 2004; Pereira et al. 2006).

P. rigida did not present marked pollen dimorphism and its pollen is described as monomorphic in palynological studies for the region (Salgado-Laboriau 1971). Despite these clear differences, morphometric analysis indicated significant differences in size between thrum and pin pollen. Pollen dimorphism is one of the most common features associated with heterostyly (Dulberger 1992), together with differences on the amount of pollen produced (McKenna 1992; Barros 1998). But distylous Rubiaceae present an enormous variation in amplitude of pollen dimorphism and in 

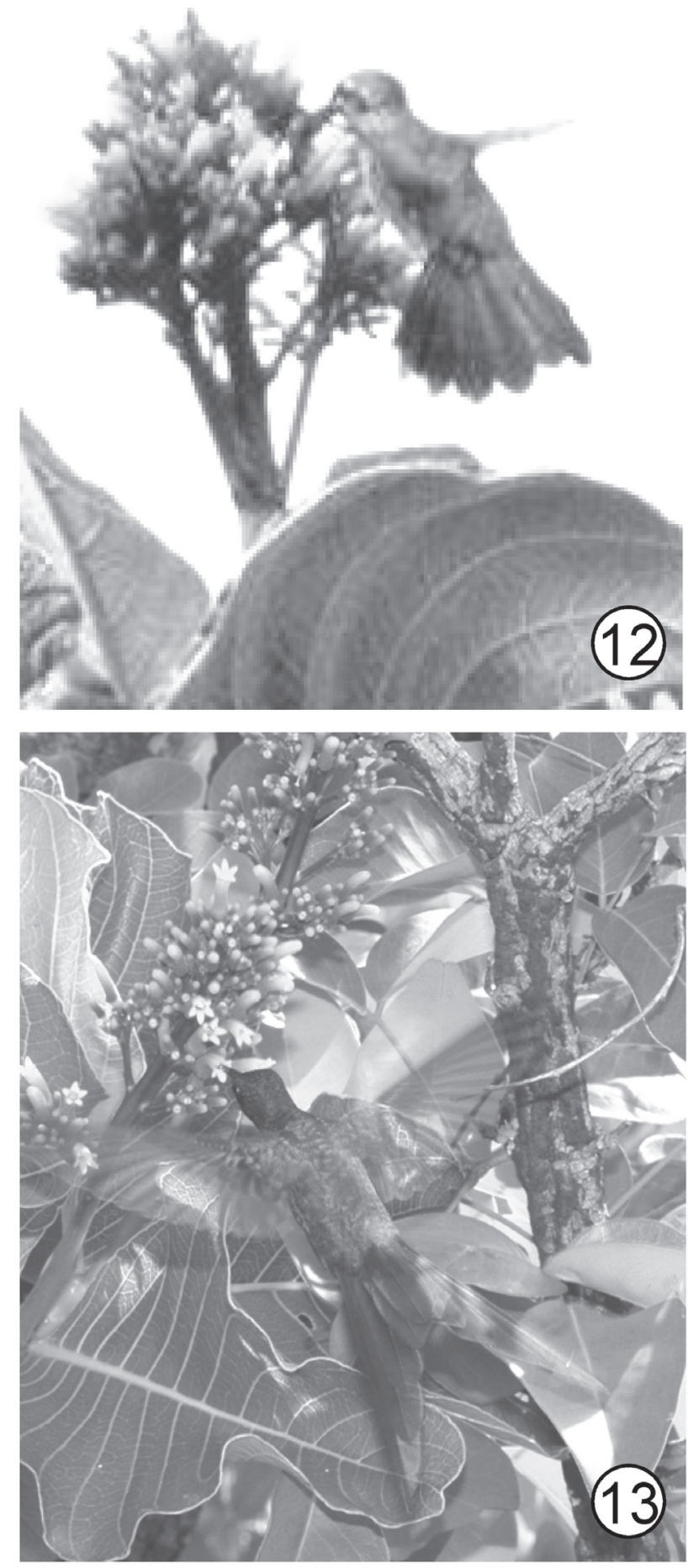

Figures 12-13. The two main hummingbird species observed visiting flowers of Palicourea rigida H. B. \& K. (Rubiaceae). 12. Colibri serrirostris (Vieillot) in the Fazenda Água Limpa area, Brasília-DF. 13. Eupetomena macroura (Gmelin) in the PESCAN area, Caldas Novas-GO.

pollen grain features (Dessein et al. 2005), with examples of very similar pollen, as in Palicourea lasiorrachis (Feinsinger \& Busby 1987).

The amount of pollen in each $P$. rigida flower is directed to cross pollination since the flower produces only two ovules. In order to secure fruit formation, some two to six pollen grains would be needed germinating on the stigma
(Cruden 1977). So, the amount of pollen grains produced in a P. rigida, flower would be enough to pollinate 500 other flowers.

There was no clear relation either between nectar production and floral morphs, contrasting with the observed for other species of Palicourea (Consolaro et al. 2009). Pin flowers of Psychotria barbiflora presented a greater volume of nectar and lower concentrations than thrum flowers (Teixeira \& Machado 2004a). Larger amounts of nectar in pin flowers were also observed for a population of Palicourea padifolia (Ornelas et al. 2004). P. rigida nectar sugar content varied between 19 and $22 \%$, concentrations similar to those found in bat-pollinated flowers (18.9\%) and hawkmoth flowers (22.1\%) (Pyke \& Waser 1981). For hummingbirds, average nectar sugar concentration is commonly a bit higher (25.4\%) but much lower than the concentration preferred by bees (41.6\%). The volume of nectar in $P$. rigida flowers was smaller than the observed in other typical hummingbird flowers (Baker 1975; Buzato et al. 2000). Smaller amounts of nectar may keep pollinators moving, obliging more visits to satisfy their energy requirements, and increasing pollen flow between plants (Navarro 1999; Coelho \& Barbosa 2003).

Reproductive success of $P$. rigida was relatively high and similar between floral morphs. Natural fruit-set results at PESCAN and CCPIU during PII was higher than the observed for the Brasília population (PI), but was similar to the observed in other Palicourea, such as P. padifolia (Ree 1997), P. petiolaris and P. fendleri (Sobrevila et al. 1983), and $P$. macrobotrys (Coelho \& Barbosa 2003; Consolaro et al. 2009). It is important to note that this latter species is homostylous and self-compatible. Other Rubiaceae, as Psychotria suterella (Lopes \& Buzato 2005), P. jasminoides (Castro et al. 2004), P. nuda (Castro \& Araújo 2004) and Sabicea cinerea (Teixeira \& Machado 2004b) presented similar fruit set results and are also markedly self-incompatible.

The reproductive efficiency of $P$. rigida is also relatively high when compared to other self-incompatible woody cerrado species which presented fruit set around 7\% (Oliveira \& Gibbs 2000). The fruit set is explained by the high frequency of pollinated pistils observed in the studied populations. The higher amount of pollen grains observed on the stigma of thrum flowers of $P$. rigida indicates a greater potential for fruit set in these plants, which contradicts the male function sometimes attributed to thrum flowers in distylous species (Monteiro et al. 1991). The higher amount of pollen grains seems to be associated with the greater stigmatic surface in these thrum flowers, as described for Palicourea fendleri (Lau \& Bosque 2003). Since incompatibility reaction in thrum flowers occurs early on the stigma, the pollen tubes growing down the style in $P$. rigida thrum-flower pistils indicate that the pollinators are efficient enough to transport pollen between floral morphs and perform legitimate cross pollination.

Palicourea rigida presented typical heteromorphic SI, with fruit set only from between morph pollinations 
Table 3. Floral visitors observed in the studied populations of Palicourea rigida H, B, \& K, (Rubiaceae) in the Fazenda Água Limpa (FAL), Parque Estadual da Serra de Caldas Novas (PESCAN) and Clube de Caça e Pesca Itororó de Uberlândia (CCPIU), Main pollinators (Main pol,), additional pollinators (additional pol,) and pillagers in each area.

\begin{tabular}{|c|c|c|c|}
\hline \multirow{2}{*}{ Flower visitor } & \multicolumn{3}{|c|}{ Category in each area } \\
\hline & FAL & PESCAN & CCPIU \\
\hline \multicolumn{4}{|l|}{ Trochilidae (hummingbirds) } \\
\hline Amazilia fimbriata (Gmelin) & Additional pol, & Additional pol, & Additional pol, \\
\hline Anthracothorax nigricollis (Vieillot) & Additional pol, & & \\
\hline Colibri serrirostris (Vieillot) & Main pol, & Additional pol, & Additional pol, \\
\hline Calliphlox amethystina $\hat{\sigma}$ & & Additional pol, & \\
\hline Chlorostilbon lucidus (Shaw, 1812) & & Additional pol, & Additional pol, \\
\hline Chrysolampis mosquitus (Linnaeus) & Additional pol, & Additional pol, & \\
\hline Eupetomena macroura (Gmelin) & & Main pol, & Main pol, \\
\hline Heliactin bilophum (Wied) & & Additional pol, & \\
\hline Thalurania furcata (Gmelin) & Additional pol, & Additional pol, & Additional pol, \\
\hline Lophornis sp (Lesson) & & Additional pol, & \\
\hline Indeterminate sp, & Additional pol, & & \\
\hline \multicolumn{4}{|l|}{ Hymenoptera } \\
\hline \multicolumn{4}{|l|}{ Apoidea } \\
\hline Apis mellifera $(\mathrm{L})$, & Additional pol, & Additional pol,/ pillager & Additional pol,/ pillager \\
\hline \multicolumn{4}{|l|}{ Bombus morio (Swederus) } \\
\hline workers & Pillager (pollen) & & \\
\hline males & Additional pol, & Additional pol, & Additional pol, \\
\hline queens & Pillager (pollen) & & \\
\hline Epicharis sp & Additional pol, & Additional pol, & \\
\hline Eulaema nigrita (Lepeletier) & Additional pol, & Additional pol, & Additional pol, \\
\hline Megachile rubricata (Smith) & Additional pol, & & \\
\hline Oxaea flavescens (Klug) & & Pillager & \\
\hline Pseudaugochloropsis graminea $(\mathrm{F})$, & Pillager & & \\
\hline Trigona spinipes $(\mathrm{F})$, & Pillager & Pillager & Pillager \\
\hline Tetragona clavipes $(\mathrm{F})$, & Pillager & & \\
\hline Halictidae sp1 & & Additional pol, & Additional pol, \\
\hline Xilocopa cf hirsutissima (Maidl) & Pillager & & \\
\hline \multicolumn{4}{|l|}{ Lepidoptera } \\
\hline Pieridae & & Additional pol, & \\
\hline \multicolumn{4}{|l|}{ Hesperiidae } \\
\hline Aguna albistria (Plötz) & Additional pol,/ Pillager & & \\
\hline Sp1 & Additional pol, & & \\
\hline $\mathrm{Sp} 2$ & Additional pol, & & \\
\hline $\mathrm{Sp} 3$ & Additional pol, & & \\
\hline $\mathrm{Sp} 4$ & Additional pol, & & \\
\hline \multicolumn{4}{|l|}{ Sphingidae } \\
\hline Aellopus sp & Additional pol, & & \\
\hline Aellopos titan (Cramer) & & Additional pol, & \\
\hline Aellopus fadus (Cramer) & Additional pol, & & \\
\hline Eupyrrhoglossum sagra (Poey) & & Additional pol, & \\
\hline
\end{tabular}


(legitimate). This self-incompatibility mechanism is associated with characteristic pollen arresting mechanisms (Bawa \& Beach 1983). The site of incompatibility reaction differed between morphs: in thrum flowers they occurred on the stigma while in pin flowers they occurred further down along the style. This pattern is similar to the observed in other distylous Rubiaceae studied (Bawa \& Beach 1983; Coelho \& Barbosa 2004; Lopes \& Buzato 2005; Pereira et al. 2006; Consolaro et al. 2009), and also for heterostylous species in other plant families (Barros 1998).

This work and other studies with Palicourea reaffirm ornithophily as the dominant pollination system in the genus. P. petiolaris and P. fendleri (Sobrevila et al. 1983), P. lasiorrachis (Feinsinger \& Busby 1987), P. macrobotrys (Coelho \& Barbosa 2003), P. padifolia (Ree 1997; Ornelas et al. 2004), and P. officinalis, P. marcgravii and $P$. coriacea (Consolaro et al. 2009) are all bird-pollinated. Many other Neotropical Rubiaceae as Psychotria nuda (Castro \& Araújo 2004), Sabicea cinerea (Teixeira \& Machado 2004b), Ferdinandusa speciosa (Castro \& Oliveira 2001) and Manettia cordifolia (Consolaro et al. 2005) also depend on hummingbirds for their pollination.

In the Serra de Caldas Novas State Park (PESCAN), no Clube Caça e Pesca (CCCPIU) and in the Fazenda Água Limpa (FAL-Brasília), P. rigida seems to be an important resource for hummingbirds during the flowering period, presenting high density of flowering individuals and many flowers. The large offer of flowers and nectar often attract territorial hummingbirds, which drive away visitors with other foraging strategies. Since $P$. rigida is self-incompatible, territorial behavior could limit between-morph pollen flow. However, the patches defended by hummingbirds usually included plants of both morphs. Moreover, territories and territorial behavior varied throughout the day and blooming period, resulting in heterogeneous pollen flow and explaining reproductive success.

Based on the populations studied, it is possible to consider $P$. rigida a typically distylous species, presenting floral dimorphism, isoplethic distribution and heteromorphic self-incompatibility. The populations differed in density and height of the individuals, but these differences did not seem to interfere with the function of distyly. Recent studies with other Cerrado species of Palicourea showed both typically distylous and anomalous species occurring in the same area, indicating that each species may respond in a different way to habitat conditions and conservation history (Consolaro et al. 2009). Despite its vast distribution in the Cerrado biome, which probably exposes its populations to different environmental pressures and habitat fragmentation, it seems that $P$. rigida did not present the distylous anomalies that have been observed in other Cerrado Rubiaceae.

\section{Acknowledgement}

We thank Amabílio Camargo, Ivone R. D. Rocha, Marcelo Bagno, Anamaria A. Ferreira and Alexandre Franchin for the identification of flower visitors. We thank CAPES for the MSc grant and the Fundação Educacional do Distrito Federal for the leave of absence for the second author. Part of the data analysis and organization of the final manuscript was done under a FAPEMIG research project (CRA 1689/2006). P.E. Oliveira also thanks $\mathrm{CNPq}$ for a productivity research grant.

\section{References}

Baker, H.G. 1956. Pollen dimorphism in the Rubiaceae. Evolution 10: 23-31. Baker, H.G. 1975. Sugar concentrations in nectar from hummingbird flowers. Biotropica 7: 37-41.

Barrett, S.C.H. \& Richards, J.H. 1990. Heterostyly in tropical plants. Memoirs of the New York Botanical Garden 55: 35-61.

Barrett, S.C.H. 1992. Heterostylous genetic polymorphisms: model systems for evolutionary analysis. Pp. 1-24. In: Barrett, S.C.H. (ed.). Evolution and function of heterostyly. Berlin, Springer-Verlag.

Barrett, S.C.H.; Jesson, L.K. \& Baker, A.M. 2000a. The evolution and function of polymorphisms in flowering plants. Annals of Botany 85: 253-265.

Barrett, S.C.H.; Wilken, D.H. \& Cole, W.W. 2000b. Heterostyly in the Lamiaceae: the case of Salvia brandegeei. Plant Systematics and Evolution 223: 211-219.

Barros, M.G. 1998. Sistemas reprodutivos e polinização em espécies simpátricas de Erythroxylum P. Br. (Erythroxylaceae) do Brasil. Revista Brasileira de Botânica 21: 159-166

Bawa, K.S. \& Beach, J.H. 1983. Self-incompatibility in the Rubiaceae of a tropical lowland forest. American Journal of Botany 70: 1281-1288.

Brower, J.E. \& J.H. Zar. 1984. Field \& laboratory methods for general ecology. Duduque, W.C. Brown Publishers.

Brys, R.; Jacquemyn, H. \& Hermy, M. 2007. Impact of mate availability, population size, and spatial aggregation of morphs on sexual reproduction in a distylous, aquatic plant. American Journal of Botany 94: 119-127.

Bullock, S.H. 1985. Breeding systems in the flora of a tropical deciduous forest. Biotropica 17: 287-301.

Buzato, S.; Sazima, M. \& Sazima, I. 2000. Hummingbird-pollinated floras at three Atlantic Forest sites. Biotropica 32: 824-841.

Castro, C.C. \& Araújo, A.C. 2004. Distyly and sequential pollinators of Psychotria nuda (Rubiaceae) in the Atlantic rain forest, Brazil. Plant Systematics and Evolution 244: 131-139.

Castro, C.C. \& Oliveira, P.E.A.M. 2001. Reproductive biology of the protandrous Ferdinandusa speciosa Pohl (Rubiaceae) in southeastern Brazil. Revista Brasileira de Botânica 24: 167-172.

Castro, C.C. \& Oliveira P.E.A.M. 2002. Pollination boiology of distylous Rubiaceae in the Atlantic Rain Forest, SE Brazil. Plant Biology 4: 640-646.

Castro, C.C.; Oliveira, P.E.A.M. \& Alves, M.C. 2004. Breeding system and floral morphometry of distylous Psychotria L. species in the Atlantic Rain Forest, SE Brazil. Plant Biology 6: 1-6.

Coelho.C.P. \& Barbosa, A.A.A. 2003. Biologia reprodutiva de Palicourea macrobotrys Ruiz \& Pavon (Rubiaceae): um possível caso de homostilia no gênero Palicourea Aubl. Revista Brasileira de Botânica 26: 403-413.

Coelho.C.P. \& Barbosa, A.A.A. 2004. Biologia reprodutiva de Psychotria poeppigiana Mült. Arg. (Rubiaceae) em mata de galeria. Acta Botanica Brasilica 18: 481-489.

Consolaro, H. 2008. A distilia em espécies de Rubiaceae do bioma Cerrado. Tese de Doutorado. Universidade de Brasília, Brasil.

Consolaro, H; Silva, E.B. \& Oliveira, P.E. 2005. Variação floral e biologia reprodutiva de Manettia cordifolia Mart. (Rubiaceae). Revista Brasileira de Botânica 28: 85-94.

Consolaro, H.; Toledo, R.; Ferreguti, R.; Hay, J.V. \& Oliveira, P.E. 2009. Distilia e homostilia em espécies de Palicourea Aubl. (Rubiaceae) do Cerrado do Brasil Central. Revista Brasileira de Botânica 32: 655-667

Cruden, R.W. 1977. Pollen-ovule ratios: a conservative indicator of breeding systems in flowering plants. Evolution 31: 32-46.

Dafni, A. 1992. Pollination Ecology - A practical approach. Oxford, IRL Press at Oxford University Press.

Darwin C. 1877. The different forms of flowers and plants of the same species. London, John Murray.

Delprete, P.G.; Smith, L.B. \& Klein, R.M. 2004. Flora Ilustrada Catarinense: Rubiaceae. Pp. 1-344. In: Reis, A. (ed.). Vol. I - Gêneros A - G: 1. Alseis até 19. Galium. Itajaí, Herbário Barbosa Rodrigues. 
Dessein, S.; Ochoterena, H.; Block, P.; Lens, F.; Robbrecht, E.; Schols, P.; Smets, E.; Vinckier, S. \& Huysmans, S. 2005. Palynological characters and their phylogenetic signal in Rubiaceae. Botanical Review. 71: 354-414.

Dulberger, R. 1992. Floral polymorphisms and their functional significance in the heterostylous syndrome. Pp. 41-77. In: Barrett, S.C.H. (ed.). Evolution and function of heterostyly. Berlin, Springer-Verlag.

Feinsinger, P. \& Busby, W.H. 1987. Pollen carryover: experimental comparisons between morphs of Palicourea lasiorrachis (Rubiaceae) a distylous, bird-pollinated, tropical treelet. Oecologia 73: 231-235.

Ganders, F.R. 1976. Pollen flow in distylous populations of Amsinckia (Boraginaceae). Canadian Journal of Botany 54: 2530-2535.

Ganders, F.R. 1979. The biology of heterostyly. New Zealand Journal of Botany 17: 607-635.

Gibbs, P. 1990. Self-incompatibility in flowering plants: a neotropical perspective. Revista Brasileira de Botânica 13: 125-136.

Heslop-Harrison, Y. \& Shivanna, K.R. 1977. The receptive surface of the angiosperm stigma. Annals of Botany 41: 1233-1258.

Johnston, I.M. 1952. Studies in Boraginaceae XXIII. A survey of the genus Lithospermum. Journal of the Arnold Arboretum 33: 299-363.

Kearns, C.A. \& Inouye, D.W. 1993. Techniques for Pollination Biologists. Niwot, University Press of Colorado.

Lau, P. \& Bosque, C. 2003. Pollen flow in the distylous Palicourea fendleri (Rubiaceae): an experimental test of the disassortative pollen flow hypothesis. Oecologia 135: 593-600.

Levin, D.A. 1968. The breeding system of Lithospermum caroliniense: adaptation and counteradaptation. American Naturalist 102: 427-441.

Li, P. \& Johnston, M.O. 2001. Comparative floral morphometrics of distyly and homostyly in three evolutionary lineages of Amsinckia (Boraginaceae). Canadian Journal of Botany 79: 1332-1348.

Lima, H.A. 1986. Contribuição ao estudo da Biologia Floral, da Fenologia e do Sistema de Reprodução de Psychotria leiocarpa Cham. et Schl. (Rubiaceae). Dissertação de Mestrado. Univereidade Federal do Rio de Janeiro, Brasil.

Lopes, L.E. \& Buzato, S. 2005. Biologia reprodutiva de Psychotria suterella Muell. Arg. (Rubiaceae) e a abordagem de escalas ecológicas para a fenologia de floração e frutificação. Revista Brasileira de Botânica 28: 785-795.

Martin, F.N. 1959. Staining and observing pollen tubes in the style by means of fluorescence. Stain Techniques 34: 125.

McKenna, M.A. 1992. Pollen competition in heterostylous plants. Pp. 225246. In: Barrett, S.C.H (ed.). Evolution and function of heterostyly. Berlin, Springer-Verlag.

Mendonça, R.C., Felfili, J.M., Walter, B.M.T., Silva-Júnior, M.C., Rezende, A.V., Filgueiras, T.S., Nogueira, P.E. \& Fagg, C.W. 2008. Flora vascular do bioma Cerrado: checklist com 12.356 espécies. Pp. 421-1279. In: Sano, S.M.; Almeida, S.P. \& Ribeiro, J.F. (orgs.). Cerrado: ecologia e flora. Brasília, DF, EMBRAPA.

Monteiro, R.; Nakajima, J.N.; Ribeiro, J.L.S. \& Toledo, J.C. 1991. Morfologia e distribuição espacial das formas heterostílicas de Psychotria barbiflora DC. (Rubiaceae). Naturalia 16: 137-146.

Murray, B.G. 1990. Heterostyly and pollen-tube interactions in Luculia gratissima (Rubiaceae). Annals of Botany 65: 691-698.

Navarro, L. 1999. Pollination ecology and effect of nectar removal in Macleania bullata (Ericaceae). Biotropica 4: 618-625.

Newstrom, L.E.; Frankie, G.W. \& Baker, H.G. 1994. A new classification for plant phenology based on flowering patterns in lowland tropical rain forest trees at La Selva, Costa Rica. Biotropica 26 (2): 141-159.

Oliveira, P.E.A.M. 2008. Fenologia e biologia reprodutiva das espécies de Cerrado. Pp. 273-290. In: Sano, S.M.; Almeida, S.P. \& Ribeiro, J.F. (orgs). Cerrado: ecologia e flora. Brasília, EMBRAPA.

Oliveira, P.E. \& Gibbs, P.E. 2000. Reproductive biology of woody plants in a cerrado community of Central Brazil. Flora 195: 311-329.

Ornduff, R. 1971. The reproductive system of Jepsonia heterandra. Evolution 25: 300-311.

Ornduff, R. 1975. Heterostyly and pollen flow in Hypericum aegypticum (Guttiferae). Botanical Journal of the Linnean Society 71: 51-57

Ornduff, R. 1976. The reprodutive system of Amsinckia grandiflora, a distylous species. Sistematic Botany 1: 57-66

Ornduff, R. 1980. Heterostyly, population composition and pollen flow in Hedyotis caerulea. American Journal of Botany 67: 95-103.
Ornelas, J.F.; Gonzáles, C.; Jiménez, L.; Lara, C. \& Martinéz, A.J. 2004. Reproductive ecology of distylous Palicourea padifolia (Rubiaceae) in a tropical montane cloud forest. II. Attracting and rewarding mutualistic and antagonistic visitors. American Journal of Botany 91: 1061-1069.

Pereira, Z.V.; Vieira, M.F. \& Carvalho-Okano, R.M. 2006. Fenologia da floração, morfologia floral e sistema de incompatibilidade em espécies distílicas de Rubiaceae em fragmento florestal do Sudeste brasileiro. Revista Brasileira de Botânica 29: 471-480.

Pyke, G.H. \& Waser, N.M. 1981. The production of dilute nectars by hummingbird and honeyeater flowers. Biotropica 13: 260-270.

Ratter, J.A.; Bridgewater, S. \& Ribeiro, J.F. 2003. Analysis of the floristic composition of the brasilian cerradão vegetation III: comparison of the woody vegetation of 376 areas. Edinburgh Journal of Botany 60: $57-109$

Ree, R.H. 1997. Pollen flow, fecundity and the adaptive significance of heterostyly in Palicourea padifolia (Rubiaceae). Biotropica 29: 298-308.

Ribeiro, J.F. \& Walter, B.M.T. 2008. As principais fitofisionomias do bioma Cerrado. Pp.151-212. In: SANO, S.M.; ALMEIDA, S.P. \& RIBEIRO, J.F. (orgs.). Cerrado: ecologia e flora. Brasília, EMBRAPA.

Richards, J.H. \& Koptur, S. 1993. Floral variation and distyly in Guettarda scabra (Rubiaceae). American Journal of Botany 80 (1): 31-40.

Robbrecht, E. 1988. Tropical woody Rubiaceae. Opera Botanica, 1: 1-271.

Rossi, A.A.B.; Oliveira, L.O. \& Vieira, M.F. 2005. Distyly and variation in floral traits in natural populations of Psychotria ipecacuanha (Brot.) Stokes (Rubiaceae). Revista Brasileira de Botânica 28 (2): 285-294.

Salgado-Laboriau, M.L. 1971. Contribuição à palinologia dos cerrados. Rio de Janeiro, RJ, FNDCT/ Academia Brasileira de Ciências.

Silva, A.P. 1995. Biologia reprodutiva e polinização de Palicourea rigida H.B.K. (Rubiaceae). Dissertação de Mestrado. UnB.

Silva-Júnior, M.C. 2005. 100 Árvores do Cerrado - guia de campo. Brasília, DF, Rede de Sementes do Cerrado.

Smith, G.F. \& Tiedt, L.R. 1991. A rapid, non-destructive osmium tetroxide technique for preparing pollen for scanning electron microscopy. Taxon 40: 195-200.

Sobrevila, C. \& Arroyo M.T. 1982. Breeding systems in a montane tropical cloud forest in Venezuela. Plant Systematic and Evolution 140: 19-37.

Sobrevila, C.; Ramirez, N. \& Enrech, N.X. 1983. Reproductive biology of Palicourea fendleri and P. petiolaris (Rubiaceae) heterostylous shrubs of a tropical cloud forest in Venezuela. Biotropica 15: 161-169.

Souza, V.C. \& Lorenzi, H. 2005. Botânica Sistemática: guia ilustrado para identificação das famílias de Angiospermas da flora brasileira, baseado em APG II. Nova Odessa, Instituto Plantarun.

StatSoft Inc. 2001. Statistica (data analysis software system), version 6. www.statsoft.com

Stone, J.L. 1995. Pollen donation patterns in a tropical distylous shrubs (Psychotria suerrens; Rubiaceae). American Journal of Botany 82: 1390-1398.

Taylor, C.M. 1997. Conspectus of the genus Palicourea (Rubiaceae: Psychotriae) with the description of some new species from Ecuador and Colombia. Annals of the Missouri Botanical Garden 84: 224-262.

Teixeira, L.A.G. \& Machado, I.C. 2004a. Biologia da polinização e sistema reprodutivo de Psychotria barbiflora DC. (Rubiaceae). Acta Botanica Brasilica 18: 853-862.

Teixeira, L.A.G. \& Machado. I.C. 2004b. Sabicea cinerea Aub1. (Rubiaceae): distilia e polinização em um fragmento de floresta Atlântica em Pernambuco, Nordeste do Brasil. Revista Brasileira de Botânica 27: 193-204.

Toledo, R.; Carvalho, A.; Hashimoto, D.; Rodrigues, M.; Ferreguti, R.; Consolaro, H.; Hay, J.V. \& Oliveira, P.E. 2007. Caracterização Morfológica de Quatro Espécies de Palicourea Aubl. (Rubiaceae) do Cerrado do Brasil Central. Revista Brasileira de Biociências 5: $732-734$

Vallejo-Marín, M. \& Barrett, S.C.H. 2009. Modification of flower architecture during early stages in the evolution of self-fertilization. Annals of Botany 103: 951-962.

Vuilleumier, B.S. 1967. The origin and evolutionary development of heterostyly in the angiosperms. Evolution 21: 210-226.

Wütherich, D.; Azócar, A.; García-Nuñez, C. \& Silva, J.F. 2001. Seed dispersal in Palicourea rigida, a common treelet species from Neotropical savannas. Journal of Tropical Ecology 17: 449-458. 